\title{
Gambaran Pola Asuh Ibu dengan Balita Stunting dan Tidak Stunting di Kelurahan Tengah, Kecamatan Kramat Jati, DKI Jakarta
}

\section{Overview of Mothers Parenting Patterns with Stunting and Non-Stunting Toddlers in the Tengah Urban-Village, Kramat Jati Sub-District, DKI Jakarta}

\author{
Hira Fitriani Aisyah ${ }^{1}$ \\ ${ }^{1}$ Departemen Pendidikan Kesehatan dan Ilmu Perilaku, Fakultas Kesehatan Masyarakat, Universitas \\ Indonesia, Kampus UI Depok 16424, Indonesia \\ *Korespondensi penulis: \\ hirafitrianiaisyah@gmail.com

$\begin{array}{ll}\text { Diterima (Recieved) } & : 23 \text { Agustus } 2021 \\ \text { Direvisi (Revised) } & : 24 \text { Desember } 2021 \\ \text { Diterima untuk diterbitkan (Accepted) } & : 25 \text { Desember } 2021\end{array}$

\begin{abstract}
ABSTRAK
Latar Belakang. Wilayah Jakarta Timur menduduki posisi lokasi fokus stunting, salah satunya di Kelurahan Tengah. Berdasarkan pengolahan data awal, diketahui prevalensi stunting pada enam posyandu di dua RW terpilih mencapai angka 25,9\%.

Tujuan. Mengetahui perbandingan pola asuh balita stunting dan tidak stunting di Kelurahan Tengah, Kecamatan Kramat Jati

Metode. Penelitian kualitatif dengan pendekatan studi kasus melalui wawancara mendalam secara daring. Sampel dipilih secara purposive sampling sesuai kriteria inklusi dan eksklusi dengan 12 informan utama yang memiliki balita stunting dan tidak stunting usia 24-59 bulan, serta informan kunci terdiri dari, Tenaga Pelaksana Gizi dan kader posyandu.

Hasil. Hasil penelitian terhadap informan utama dengan balita stunting menunjukkan bahwa sebagian besar ibu tidak memberikan ASI Eksklusif kepada anaknya, memberikan makan dengan frekuensi yang kurang, variasi makanan tidak beragam karena anak banyak diberikan jajanan. Selain itu, ibu dengan anak stunting juga mendapatkan dukungan psikososial yang rendah serta rendahnya partisipasi ke Posyandu.

Kesimpulan. Terdapat perbedaan antara pola asuh ibu dengan balita stunting dan ibu dengan balita tidak stunting.
\end{abstract}

Kata Kunci:; Stunting; Pola Asuh Ibu, Balita

\section{ABSTRACT}

Background. East Jakarta region has become the primary location of stunting, one of which is Tengah Village. Based on the weighing and preliminary data, the prevalence of stunting in 6 Posyandu in the two selected RWs reached $25.9 \%$.

Objective to find out the comparison of parenting patterns of stunting toddlers and non-stunting toddlers in Tengah Urban-Village, Kramat Jati Sub-District

Method. This research is qualitative, with a case-study approach and collected through in-depth online interviews. The sample was selected by purposive sampling, based on the inclusion and exclusion criteria which 12 main informants had stunting and not stunting toddlers aged 24-59 months and key informants consisting of Nutrition Workers in the Puskesmas Tengah and Posyandu cadres.

Results. The research results on key informants with stunting toddlers show that most mothers didn't give exclusive breastfeeding to their children, provide food with less frequency, food variations are not varied because children are given a lot of snacks. Mothers with stunting toddlers also experienced low psychosocial support and low participation in Posyandu.

Conclusion. There is a difference between mothers with stunting toddlers' parenting patterns and mothers with non-stunting toddlers.

Keywords: stunting, mother's parenting pattern, toddlers 


\section{LATAR BELAKANG}

Stunting pada anak merupakan salah satu hambatan paling signifikan bagi perkembangan manusia, secara global mempengaruhi sekitar 162 juta anak di bawah usia 5 tahun. ${ }^{1}$ Stunting, atau terlalu pendek untuk usia seseorang, didefinisikan sebagai tinggi badan yang lebih dari dua standar deviasi di bawah median standar pertumbuhan anak Organisasi Kesehatan Dunia (WHO). ${ }^{1}$ Pendek sebagai salah satu indikator stunting dijadikan sebagai "penanda" bahwa seorang anak sedang pada lingkungan yang defisit untuk dirinya dalam melakukan proses tumbuh dan kembang. ${ }^{2}$ Akibat jangka panjangnya adalah kemampuan kognitif dan prestasi belajar yang menurun, melemahnya kekebalan tubuh. Anak akan lebih sering terkena penyakit dan memiliki resiko tinggi menderita diabetes, kegemukan, penyakit jantung, dan pembuluh darah, stroke, kanker, disabilitas pada usia tua dan kualitas kerja yang tidak kompetitif dan rendahnya produktivitas ekonomi. ${ }^{2}$

\section{Berdasarkan Childhood Stunting:}

Context, Causes and Consequences, WHO Conceptual Framework, ${ }^{3}$ stunting disebabkan oleh beberapa faktor. Antara lain pola pengasuhan di dalam keluarga meliputi keadaan gizi pada saat kehamilan dan lingkungan rumah, pemberian asupan makanan yang tidak adekuat, praktik pemberian ASI dan MP ASI yang tidak baik serta adanya penyakit infeksi. Faktor penyebab stunting terdiri atas penyebab langsung dan penyebab tidak langsung. Faktor penyebab langsung stunting, yaitu asupan makanan yang tidak adekuat, karakteristik balita meliputi usia, jenis kelamin, berat badan lahir, panjang badan lahir, dan adanya infeksi berulang. ${ }^{4}$ Faktor penyebab tidak langsung dari stunting adalah ketersediaan pangan, pola pengasuhan, serta jangkauan mutu pelayanan kesehatan masyarakat. ${ }^{4}$ Pola asuh erat kaitannya dengan peran ibu dalam kondisi saat kehamilan dan menyusui. Serangkaian perilaku kebiasaan pemberian makan pada balita meliputi pemberian ASI dan MPASI, stimulasi dan dukungan psikososial kepada anak untuk perkembangan, praktek kebersihan dan sanitasi lingkungan, serta perawatan anak saat sakit termasuk diagnosis penyakit dan pemanfaatan pelayanan kesehatan. ${ }^{4}$

Stunting secara nasional berdasarkan Hasil Riset Kesehatan Dasar (Riskesdas) Kementerian Kesehatan adalah 30,8 \% pada 2018. ${ }^{5}$ Stunting di DKI Jakarta adalah sebesar $17,7 \%{ }^{5}$ Akan tetapi, wilayah Jakarta Timur menduduki posisi tertinggi dengan prevalensi sebesar 25,7\%, dengan kategori 5.628 anak balita pendek dan 4.857 anak balita sangat pendek. ${ }^{6}$ Hal ini disebabkan karena wilayah Jakarta Timur merupakan wilayah dengan populasi penduduk terbanyak di DKI Jakarta dengan jumlah masyarakat miskin yang tinggi. Oleh karena itu Jakarta Timur disasar menjadi lokasi fokus intervensi stunting pada 2020 untuk mencegah keturunan yang mengalami stunting. ${ }^{6}$ Salah satu kecamatan di Jakarta Timur yang menjadi lokus stunting berada di Kecamatan Kramat Jati. Berdasarkan data operasi timbang Human Initiative di enam posyandu terpilih pada Februari 2019 di wilayah kerja Puskesmas Kelurahan Tengah, Kecamatan Kramat Jati, diketahui prevalensi stunting pada enam posyandu di dua RW terpilih mencapai angka $25,9 \%$. Penelitian in bertujuan ingin mengetahui secara mendalam perbandingan pola asuh ibu dengan balita stunting dan tidak stunting di Kelurahan Tengah, Kecamatan Kramat Jati.

\section{METODE}

Penelitian ini menggunakan metode kualitatif dengan desain penelitian studi kasus. Penelitian ini dilakukan pada bulan Mei-Juni 2020 di wilayah kerja Puskesmas Kelurahan Tengah Kecamatan Kramat Jati, Jakarta Timur tepatnya di RW 04 dan RW 07. Pemilihan wilayah dikarenakan prevalensi stunting yang tinggi (TB/U: 25,9\%) dan lokasi yang berdekatan dengan pasar induk di mana mayoritas ibu bekerja sebagai pengupas bawang.

Informan utama penelitian ini terdiri dari 12 ibu pekerja pengupas bawang yang memiliki anak balita stunting dan tidak stunting usia 24-59 bulan. Karakteristik informan utama dibedakan dengan kriteria status kepemilikan rumah (milik sendiri atau mengontrak) dan status tinggal bersama (keluarga inti atau keluarga besar). Informan kunci terdiri dari dua orang yaitu pengasuh keluarga, Tenaga 
Pelaksana Gizi (TPG) Puskesmas Kelurahan Tengah dan Kader Kelurahan Tengah, Kecamatan Kramat Jati, Jakarta Timur.

Wawancara dilakukan secara daring menggunakan pedoman wawancara. Metode daring seperti via telepon seluler atau melalui aplikasi yang menyediakan fitur percakapan suara dan gambar seperti aplikasi Whatsapp. Persetujuan untuk menjadi informan pada penelitian ini ditanyakan melalui pesan kepada informan. Informan menjawab setuju atau tidak setuju lewat pesan singkat.

Uji validitas data melalui triangulasi sumber dan analisis. Triangulasi sumber akan dilakukan wawancara dengan informan keluarga yaitu pengasuh selain ibu dan informan kunci kunci yaitu Tenaga Pelaksana Gizi (TPG) Puskesmas Kelurahan Tengah dan Kader Kelurahan Tengah, Kecamatan Kramat Jati, Jakarta Timur. Triangulasi analisis akan dilakukan oleh peneliti dan pembimbing akademik.

Faktor yang akan diteliti pada penelitian ini berfokus pada pola asuh diantaranya adalah kebiasaan pemberian ASI, kebiasaan pemberian MPASI, kebiasaan cara pemberian makan, dukungan psikososial, kebersihan dan sanitasi, serta pemeliharaan kesehatan anak.

\section{HASIL}

\section{Pemberian ASI Eksklusif}

Sebagian besar informan dengan balita stunting dan informan dengan balita tidak stunting melakukan IMD. Pada umumnya bayi dilahirkan di bidan atau rumah sakit bukan dukun. Jeda waktu menyusui sekitar 2-4 jam setelah melahirkan. Sebagian besar informan dengan balita stunting memberikan ASI Eksklusif kepada anaknya, walaupun ada beberapa yang tidak memberikan ASI secara eksklusif. Seluruh informan dengan balita tidak stunting memberikan ASI Eksklusif kepada anaknya. Penyapihan Seluruh informan yang menyusui anaknya dengan ASI sebagian besar menyapih anak pada usia dua tahun.

"..abis lahiran bayinya langsung ditaro di dada saya nyari-nyari tete" (informan $\mathrm{O}$ dengan balita stunting)

"saya eksklusif mbak 6 bulan ASI biar imun anak saya kuat kalo kata bu bidan di posyandu, saya mah ngikut aja ya..” (informan $\mathrm{N}$ dengan balita tidak stunting)

"saya sih kayak orang-orang aja mbak, pada berenti nyusuin 2 tahun ya.. kata tetangga saya juga begitu" (informan $\mathrm{P}$ dengan balita stunting)

\section{Pemberian MPASI}

Sebagian informan dengan balita stunting memberikan MPASI saat anak berusia 6 bulan. Ada beberapa informan dengan balita stunting yang sudah memberikan makan kepada anaknya sejak umur 4 bulan dan 5 bulan. Alasan mereka karena sudah turun temurun di keluarga mereka memberi makan anak sebelum usia enam bulan. Seluruh informan dengan balita tidak stunting memberikan MPASI kepada anaknya pada usia enam bulan. Sebagian besar informan dengan balita stunting memberikan makan kepada anaknya dua kali sehari, pagi dan sore. Informan dengan balita tidak stunting sebagian besar memberikan makan tiga kali sehari pagi, siang, dan sore. Jenis makanan yang diberikan oleh informan dengan balita stunting sehari-hari adalah nasi, sumber protein nabati seperti tempe dan tahu, protein hewani seperti telur. Jenis makanan yang tidak adekuat yaitu hanya satu telur dalam satu hari dan itu kadang tidak habis. Bahkan ada informan yang mengaku makan satu telur dadar goreng untuk dibagi empat orang anggota keluarga. Jenis makanan yang diberikan oleh informan dengan balita tidak stunting sehari-hari adalah nasi, lauk sumber protein hewani seperti tempe dan tahu, protein hewani seperti telur, ayam, dan ikan diberikan 3-5 kali dalam seminggu. Cemilan yang diberikan informan dengan balita stunting kepada anaknya antara lain adalah ciki, biskuit, sosis goreng, otak-otak goreng yang dibeli di warung, sedangkan untuk informan dengan balita tidak stunting sebagian besar lebih rajin membuatkan cemilan sendiri untuk anaknya seperti puding, donat kentang, dan pizza rumahan.

"saya udah kasih paya dikerok pas anak saya umur 5 bulan mbak.. gapapa sih sepupunya juga pada begitu.." (informan $\mathrm{P}$ dengan balita stunting)

"saya biasanya pagi sama sore sih kalo makan gitu, atau pagi sama siang nanti 
sorenya buah, cemilan biscuit sesuka anaknya aja"'(informan $\mathrm{V}$ dengan balita tidak stunting)

"..apalagi kalo bapaknya sepi manggul, saya kupasan sedikit, kadang makan telor 1 dibagi 4 mbak pake kecap aja.. sedihsih tapi mau gimana lagi"'(informan E dengan balita stunting)

"saya suka bikin cemilan kayak donat, pizza buat dia dijual juga kadang kalo ada yang mesen.. "(informan I dengan balita tidak stunting)

\section{Kebiasaan Cara Pemberian Makan}

Seluruh informan dengan balita stunting dan informan dengan balita tidak stunting menawarkan makan kepada anaknya. Cara informan dengan balita stunting dan informan dengan balita tidak stunting memotivasi anak untuk makan sebagian adalah dengan ditakuttakuti, sebagian lagi ada yang sambil diajak main dan mengobrol dan ada juga yang didiamkan saja sampai anak meminta makan. Seluruh informan menjawab yang mengalihkan perhatian anak saat makan adalah ajakan main dari teman sebayanya. Posisi dan kondisi anak informan dengan balita stunting saat makan sebagian besar duduk sambil bermain, ibu sambil mengupas bawang dan terkadang anak tidak mau disuapi ibunya karena tangan ibu bau bawang. Sebagian besar informan dengan balita tidak stunting menyuapi anak setelah selesai mengupas bawang dengan alasan lebih fokus dan lega jika pekerjaan sudah selesai. Pada saat anak sakit informan dengan balita stunting sebagian besar memberikan porsi makanan yang lebih sedikit dari biasanya karena mengikuti selera makan anak yang tidak baik. Sebagian besar informan dengan balita tidak stunting tetap mengusahakan anaknya makan pada saat sakit misalnya dengan makan bubur, atau minum the manis hangat supaya tetap ada tenaga.

"saya nanya dulu dia laper gak, kalo jawab enggak ya ga makan walaupun jam nya makan, nanti aja pas dia minta"(informan $\mathrm{P}$ dengan balita stunting)

“..nakutin bilang kalo gak makan disamperin ondel ondel loh.." (informan U dengan balita tidak stunting)

"dia mah kalo gamau makan ngelepeh abis itu nangis deh kalo saya gak ngebolehin main.."(informan V dengan balita tidak stunting)

“..bawang selesai baru deh ngurus anak, kalo bisa sebelum jam 12 slesai kasih makan anak biar makannya banyak"(informan A dengan balita tidak stunting)

"si adek kalo lagi sakit susah makan, dipaksain dia nangis..saya pusing yaudah nunggu dia diem dulu aja "(informan O dengan balita stunting)

\section{Dukungan Psikososial}

Informan dengan balita stunting dan informan dengan balita tidak stunting sebagian besar melakukan kegiatan bersama anak mereka secara aktif berupa bermain, nonton tv bersama, bercanda, dan bernyanyi. Walaupun ada informan dengan balita stunting yang jarang berinteraksi dengan anaknya karena sibuk mengupas bawang sehingga anak cenderung pendiam dan anak lebih sering berinteraksi dengan ayahnya.

“..cerewet banget apa aja diobrolin sama saya, nyanyi kek liat yutub, nanya apa aja yang dia kepo-in.. "(informan U dengan balita tidak stunting)

Diperkuat hasil wawancara dengan suami informan D yaitu bapak A yang menjelaskan bahwa anaknya lebih sering berinteraksi dengan dirinya. Hal ini dikarenakan ibunya yang sibuk mengupas bawang dan mengerjakan pekerjaan rumah.

"iyaa.. seringnya becanda sama saya.. ibunya galak. kerja terus hehe jadi anaknya kadang ga betah atau suka nangis, jadi manjanya ke saya aja gituh mba hehe"(informan keluarga A dengan balita stunting)

Informan dengan balita stunting dan informan dengan balita tidak stunting sebagian besar sering membawa anak bermain ke rumah tetangganya, karena dekat dan memiliki anak yang sebaya sehingga bisa bermain bersama.

"main disitu aja depan rumah sama tetangga..udah anteng kita liatin sambil ngupas, kadang kalo bosen ke rumah neneknya" (informan P dengan balita stunting)

Informan dengan balita stunting sebagian besar jarang membelikan mainan untuk anak dikarenakan kondisi uang yang tidak memungkinkan dan mainan yang sudah dibeli 
mubazir atau anak cepat bosan. Informan dengan balita tidak stunting sebagian besar sering membelikan mainan untuk anak 2-3 kali dalam sebulan dengan alasan untuk membahagiakan anak agar mau makan banyak dan tidak bosan main di rumah.

“..saya biasanya minjem aja ke tetangga, sehari-dua hari mainannya di rumah saya, nanti kalo anak saya udah bosen, dikembalikan.." (informan M dengan balita stunting)

"kalo lagi jalan sama dia kayak ke mol gitu dia nunjuk apa saya beliin.. biar seneng aja mbak, kan kita juga seneng liatnya.."(informan A dengan balita tidak stunting)

\section{Kebersihan dan Sanitasi}

Seluruh informan dengan balita stunting dan informan dengan balita tidak stunting selalu mencuci tangan sebelum menyuapi anak mereka makan dengan alasan takut kotor, terkena bakteri dan membuat anak cacingan jika tidak cuci tangan. Sebagian besar informan dengan balita stunting mengaku jarang memandikan anak mereka dikarenakan sibuk mengupas bawang dan anak yang susah dimandikan. Sebagian besar informan dengan balita stunting selalu memandikan anak mereka dua kali sehari karena sudah dibiasakan dan terkadang anak ingin mandi dan meminta kepada ibunya. Sumber air rumah informan dengan balita stunting dan informan dengan balita tidak stunting sebagian besar berasal dari air tanah atau biasa disebut memakai sanyo. Untuk sumber air minum, sebagian besar informan membeli air galon isi ulang dikarenakan air sumur atau tanah biasanya berwarna dan berbau. Walaupun ada beberapa informan dengan balita tidak stunting yang memasak air tanah untuk air minum yang dikonsumsi di rumah. Untuk fasilitas sanitasi seluruh informan dengan balita tidak stunting memiliki toilet di dalam rumah, sedangkan ada beberapa informan dengan balita stunting yang menggunakan MCK umum.

"..ya cuci tangan pake air aja gak pake sabun, menurut saya udah bersih sih.." (informan $\mathrm{O}$ dengan balita stunting)

"anak mah pagi kudu mandi sama makan dulu biar saya tenang gitu mau ngapa ngapain sama sore deh dia kalo abis main kan lengket badannya suka minta mandi 'buk mandi buk' gitu.." (informan dengan balita tidak stunting) "sanyo buat mandi sama cuci cuci aja kalo buat minum mah pake air isi ulang..yang 5 ribuan"'(informan $\mathrm{P}$ dengan balita stunting)

"kamar mandinya rame-rame kak, ada 6 keluarga kayaknya 2 kamar mandi di luar. Kita pake wc yang nongkrong gitu semuanya. Enakan we nongkrong sih lebih nyaman daripada duduk kayak ngeganjel gitu" (informan D dengan balita stunting)

\section{Pemeliharaan Kesehatan Anak}

Beberapa informan dengan balita stunting mengaku jarang ke posyandu karena sudah repot mengurus pekerjaan di rumah, males karena terlalu pagi. Datang ke posyandu hanya pada saat imunisasi, pembagian vitamin dan obat cacing saja. Bahkan ada beberapa informan yang menitipkan anaknya ke tetangga untuk ikut posyandu. Seluruh informan dengan balita tidak stunting aktif ke posyandu. Status imunisasi seluruh balita dari informan sudah lengkap. Sebagian besar informan dengan balita stunting mengaku bahwa anak mereka sering terkena penyakit seperti pilek, batuk dan diare. Sebagian besar menjawab penyebab diare karena salah makan, dan bawaan karena musim hujan. Ada juga yang memaklumi karena penyakit anak kecil kebanyakan pilek, batuk dan diare.

"kadang kalo pagi kan repot mbak, ga keburu deh ngurus anak ke posyandu. Disamper samperin tuh sama kadernya, tapi saya nitipin aja anak saya sama tetangga yang penting setor muka ntar pulangnya saya tanya berat badannya aja sama kadang bawa makanan gitu kan kayak biscuit buah pisang atau pudding" (informan D dengan balita stunting)

"saya dibilangin sama orang puskesmas yang penting imunisasi harus lengkap biar anaknya gak gampang sakit.." (informan M dengan balita stunting)

"kalo batuk, pilek gitu sering kadang mencret-mencret dia kalo abis salah jajan atau gara-gara lagi musim ujan juga yak maklum Namanya bocah maen ga tau juntrungannye.." (informan $\mathrm{M}$ dengan balita stunting) 


\section{PEMBAHASAN}

\section{Kebiasaan Pemberian ASI}

Pada penelitian ini hampir sebagian besar informan dengan balita stunting dan tidak stunting melakukan IMD. Hal ini sejalan dengan penelitian Nadiyah ${ }^{7}$ yang menyatakan bahwa IMD tidak berhubungan signifikan dengan stunting. Informan dengan balita tidak stunting seluruhnya memberikan anak mereka ASI Eksklusif, sedangkan sebagian besar informan dengan balita stunting tidak memberikan ASI Eksklusif. Hasil penelitian yang serupa oleh $\mathrm{Kahfi}^{7}$ yaitu bahwa sebagian besar ibu yang memiliki anak stunting tidak memberikan ASI Eksklusif pada anak mereka. Hal ini sejalan dengan penelitian yang dilakukan oleh Permadi $^{9}$ yang menyatakan bahwa ASI Eksklusif berpengaruh terhadap kejadian stunting, dimana bayi yang tidak diberikan ASI Eksklusif beresiko mengalami stunting 7,86 kali dari bayi yang diberikan ASI Eksklusif. Pada penelitian ini sebagian besar informan dengan balita stunting dan dengan balita tidak stunting berhenti menyusui anaknya sampai berusia 24 bulan atau 2 tahun. Pada penelitian Handayani ${ }^{10}$ dikatakan bahwa tidak terdapat hubungan yang signifikan antara umur penyapihan dengan kejadian stunting.

\section{Kebiasaan Pemberian MPASI}

Sebagian besar informan dengan balita stunting dan tidak stunting memberikan MPASI pertama kepada balita saat berusia 6 bulan. $\mathrm{WHO}^{11}$ menganjurkan bahwa bayi sudah dapat mulai menerima MP-ASI ketika berusia 6 bulan. Pada usia 6-8 bulan frekuensi pemberian MP-ASI adalah 2-3 kali, kemudian meningkat menjadi 3-4 kali ketika memasuki usia 9 bulan, makanan selingan dapat diberikan 1-2 kali pada usia berikutnya. ${ }^{11}$ Pada informan dengan balita stunting kebanyakan anaknya mengonsumsi telur yang merupakan sumber protein hewani yang bisa diserap $100 \%$. Akan tetapi frekuensi konsumsi telur hanya sebutir per harinya dan tidak adekuat, karena seharusnya konsumsi telur yang memenuhi pemenuhan gizi pada balita sebanyak 2-4 butir perharinya. Sejalan dengan penelitian Anindita ${ }^{12}$ bahwa sumber protein tidak berpengaruh langsung pada tinggi badan, tetapi tinggi badan adalah gambaran asupan protein di masa lampau.

\section{Kebiasaan Cara Pemberian Makan}

Sebagian besar informan dengan balita stunting sering memberikan jajanan jika anak mereka tidak mau makan. situasi makan sebagian besar balita stunting adalah sambil duduk dan makan sendiri sementara ibu fokus dengan pekerjaannya mengupas bawang. Sejalan dengan penelitian Hanum dan Khomsan $^{13}$ yaitu kebanyakan ibu dengan balita stunting membiarkan anak mereka makan sesuai keinginan dalam keadaan duduk disiplin. Informan dengan balita tidak stunting sebagian besar tetap membujuk dan merayu anak untuk teratur makan dalam sehari, ibu merayu dengan menakut-nakuti anak supaya tetap makan. Sejalan dengan penelitian dari Masithah et al. ${ }^{14}$ yang menyatakan untuk balita mulai susah makan pada usia satu tahun, anak tidak mau makan dan dalam jumah sedikit biasanya jarang habis. Untuk mengatasi tidak nafsu makan pada anak para ibu membujuk dan merayu anak mereka serta membolehkan anaknya untuk makan sambil bermain.

\section{Dukungan Psikososial}

Sebagian besar informan dengan balita stunting tidak aktif berinteraksi dengan anak dikarenakan sibuk mengupas bawang. Anak hanya diberikan handphone untuk bermain agar tidak menganggu ibunya saat mengupas bawang. Sebagian besar informan dengan balita tidak stunting aktif brinteraksi dengan anak mereka seperti menyanyi, dan belajar membaca. Bila ibu bekerja dan anak diasuh oleh orang lain hubungan dengan ibu menjadi kurang erat karena ibu tidak bisa mencurahkan waktu dengan sepenuhnya. ${ }^{15,16}$

\section{Kebersihan dan Sanitasi}

Penyakit yang sering terjadi pada bayi dan balita pada umumnya adalah penyakit yang memiliki kaitan erat dengan masalah lingkungan dan pola pemberian makan. Penyakit yang memiliki kaitan erat dengan masalah lingkungan diantaranya adalah diare. Penyakit infeksi parah dan berulang pada jangka waktu yang lama dapat menyebabkan stunting. Analisis yang dilakukan pada sembilan penelitian berpenghasilan rendah dengan rumah tangga yang sering terkena diare mendapatkan risiko stunting yang lebih tinggi. ${ }^{17}$ Sebagian kecil dari informan dengan balita stunting memakai MCK gabungan di 
luar rumah bukan kamar mandi di dalam rumah sendiri. Hal ini sejalan dengan penelitian Checkley et al. ${ }^{18}$ balita yang tidak mempunyai akses sanitasi yang baik mengalami defisit tinggi badan sebear $0,9 \mathrm{~cm}$ daripada balita yang memiliki akses sanitasi yang baik. Sejalan dengan penelitian $\mathrm{Kahfi}^{8}$ bahwa sebagian besar keluarga anak stunting tidak memiliki jamban sendiri.

\section{Pemeliharaan Kesehatan Anak}

Seluruh informan dengan balita stunting dan informan dengan balita tidak stunting sudah melakukan imunisasi lengkap sesuai umur kepada balita. Hal ini sejalan dengan penelitian Anisa ${ }^{19}$ yang menyatakan bahwa tidak ada hubungan yang bermakna antara status imunisasi dengan kejadian stunting pada balita. Prinsip imunisasi sendiri adalah memberikan antigen lewat vaksin dalam tubuh sehingga tubuh merespon dengan membentuk antibodi, jika seorang anak tidak diimunisasi makan tidak terbentuk antibodi sehingga ketika kuman penyakit menyerang, anak akan mudah sakit. ${ }^{20}$

\section{KESIMPULAN}

Sebagian besar informan dengan balita stunting tidak memberikan ASI Eksklusif kepada anak mereka, sedangkan informan dengan balita tidak stunting seluruhnya memberikan ASI Ekslusif. Sebagian besar informan dengan balita stunting memberikan MPASI pertama kepada anaknya adalah bubur instan pabrikan, sumber protein hewani 1-2 kali seminggu dan jarang memberikan sayur dan buah. Sebagian besar informan dengan balita tidak stunting memberikan MPASI pertama kepada anaknya bubur tim buatan sendiri dengan nasi atau ati ayam, sumber protein hewani bisa 3-5 kali dalam seminggu dan sering memberikan sayur dan buah.

Kebiasaan cara pemberian makan anak sebagian besar informan dengan balita stunting dibiarkan makan sendiri sambil ibu mengawasi dengan bekerja, sedangkan informan dengan balita tidak stunting berhenti bekerja dan menyuapi anaknya. Sebagian kecil informan dengan balita stunting memiliki akses sanitasi kurang baik dengan menggunakan MCK umum, sedangkan seluruh informan dengan balita stunting memiliki MCK sendiri di rumah.

\section{SARAN}

Penelitian ini merupakan awal dari eksplorasi gambaran pola asuh ibu pekerja pengupas bawang yang berada di sekitar Pasar Kramat Jati. Bagi pengembangan keilmuan, perlu dilakukan penelitian yang lebih mendalam tentang faktor rumah tangga dan keluarga seperti kehamilan pada ibu, hubungan dengan penyakit infeksi, serta faktor sosial dan masyarakat seperti kemampuan daya beli, dan budaya dengan kejadian stunting pada balita dengan ibu yang bekerja sebagai pengupas bawang.

\section{UCAPAN TERIMA KASIH}

Peneliti mengucapkan terima kasih kepada semua pihak dan informan yang terlibat didalam penelitian ini. Ucapan khusus untuk Puskesmas Tengah atas kerjasamanya sehingga penelitian ini dapat berjalan lancar.

\section{DAFTAR REFERENSI}

1. Global Nutrition Targets 2025: Stunting Policy Brief. Geneva: World Health Organization; 2014.

2. Leroy, JL and Frongillo, EA. 2019. "Perspective: What Does Stunting Really Mean? A Critical Review of the Evidence." Advances in Nutrition 10 (2): 196-204. https://doi.org/10.1093/advances/nmy101

3. "Childhood Stunting: Context, Causes and Consequences - WHO Conseptual framework". Geneva: World Health Organization; 2013.

4. The State of the World's Children 2019. Children, Food and Nutrition: Growing well in a changing world. New York: UNICEF; 2019

5. Kemenkes RI. Riset Kesehatan Dasar (RISKESDAS). Jakarta; 2018.

6. BAPPEDA Provinsi DKI Jakarta. 2018. Prevalensi Gizi Buruk di Jakarta Tinggi, Bappeda Adakan Forum Lintas Bidang Tentang Stunting. (online) Tersedia di: https://bappeda.jakarta.go.id/front/read/12 2 
7. Nadiyah, Briawan, D., Martianto, D., 2014. Faktor Resiko Stunting pada Anak Usia $0-23$ Bulan di Provinsi Bali, Jawa Barat, Dan Nusa Tenggara Timur. Jurnal Gizi dan Pangan, Juli 2014, 9(2): p.125132

8. Kahfi, A. 2015. Gambaran Pola Asuh Baduta Stunting usia 13-24 Bulan Di Wilayah Kerja Puskesmas Neglasari Kota Tangerang Tahun 2015. Skripsi. Program Kesehatan Masyarakat Fakultas Kedokteran dan Ilmu Kesehatan. Universitas Islam Negeri Syarif Hidayatullah Jakarta: Jakarta.

9. Permadi MR, Hanim D, Kusnandar, and Indarto D. 2016. "Risiko Inisiasi Menyusu Dini Dan Praktek Asi Eksklusif Terhadap Kejadian Stunting Pada Anak 6-24 Bulan" 63 (1): 9-14.

10. Handayani, novita puji. 2012. Hubungan Antara Karakteristik Keluarga Dengan Umur Penyapihan, Praktek Pemberian Makanan Pendamping ASI Dan Status Gizi Balita Di Kelurahan Sumur Batu Bantar Gebang Bekasi. Bogor, Institut Pertanian Bogor.

11. Infant and young child feeding [internet]. Geneva: World Health Organization; 2021 June 9 [cited 2021 Dec 5]. Available from: https://www.who.int/news-room/factsheets/detail/infant-and-young-childfeeding

12. Anindita P. Hubungan Tingkat Pendidikan Ibu, Pendapatan Keluarga, Kecukupan Protein dan Zink dengan Stunting pada Balita Usia 6-35 Bulan di Kecamatan Tembalang Kota Semarang. JKM. 2012: Vol (1): 17-26.

13. Hanum. N. L., \& Khomsan. A, "Pola Asuh Makan, Perkembangan Bahasa, Dan Kognitif Anak Balita Stunted Dan Normal Di Kelurahan Sumur Batu, Bantar Gebang Bekasi," Jurnal Gizi dan Pangan, 2012 Juli; 7(2): 81-88

14. Mashitah T, Soekirman, Martianto D. Hubungan pola asuh makan dan kesehatan dengan status gizi anak batita di Desa Mulya Harja. Media Gizi dan Keluarga. 2005; 29(2):29-39.

15. Ventura AK, Birch LL. Does parenting affect children's eating and weight status?
Int J Behav Nutr Phys Act. 2008 Mar 17;5:15. doi: 10.1186/1479-5868-5-15. PMID: 18346282; PMCID: PMC2276506. 16. Attorp, A., Scott, J.E., Yew, A.C. et al. Associations between socioeconomic, parental and home environment factors and fruit and vegetable consumption of children in grades five and six in British Columbia, Canada. BMC Public Health 14, 150 (2014). https://doi.org/10.1186/1471-2458-14-150

17. Checkley W, Buckley G, Gilman RH, Assis AMO, Guerrant RL, Morris SS, et al. Multi-country analysis of the effects of diarrhoea on childhood stunting. Int $\mathrm{J}$ Epidemiol. 2008;37:816-30. DOI: 10.1093/ije/dyn099.

18. Checkley W, Gilman RH, Black RE, Epstein LD, Cabrera L, Sterling CR, Moulton LH. Effect of water and sanitation on childhood health in a poor Peruvian peri-urban community. Lancet. 2004 Jan 10;363(9403):112-8. doi: 10.1016/S01406736(03)15261-0. PMID: 14726164.

19. Anisa, P. (2012) Faktor - Faktor Yang Berhubungan Dengan Kejadian Stunting Pada Balita Usia 25 - 60 Bulan Di Kelurahan Kalibaru Depok Tahun 2012. Universitas Indonesia

20. Vaccines and immunization: What is vaccination? [internet]. Geneva: World Health Organization; 2021 August 30 [cited 2021 Dec 5]. Available from https://www.who.int/newsroom/questions-andanswers/item/vaccines-and-immunizationwhat-is-vaccination 